\title{
The capital structure determinants of the Portuguese banking sector: A regional dynamics
}

\author{
Nuno Ricardo da Gama Vieira Ferreira de Castro \\ ISCTE - Instituto Universitário de Lisboa (Iscte Business School), \\ Lisbon, Portugal \\ nrgvfcastro@gmail.com
}

Ilídio Tomás Lopes*

ISCTE - Instituto Universitário de Lisboa (Iscte Business School), Lisbon, Portugal

ilidio.tomas.lopes@iscte-iul.pt

ORCID 0000-0002-0612-8801

*Corresponding Author

\begin{abstract}
This research focuses on evaluating how strongly common capital structure determinants have an explanatory power on the Portuguese banking financial leverage. It also assesses the impact of financial crisis on the banks' leverage ratios, and its adjustments with capital regulatory requirements. A set of banks selected correspond to the group of financial entities that form the Portuguese Bank Association and that have continually operated as a unique entity over the period 2009-2018. A panel data analysis, based on a fixed effects approach, was used to assess the relationship between financial leverage and the set of selected explanatory variables. The results evidences that there is a significant impact of regulatory capital, the global financial crisis and the eurozone crisis on the leverage levels of the Portuguese banks. Over the period under analysis, regulatory capital, as well as the economic effects of the financial crisis, strongly impacted on the leverage ratios, affecting the capital structure of Portuguese banks. This research provides key outcomes about the impact of structural capital drivers on the Portuguese leverage ratios and the corresponding levels before and after the economic financial crisis. It confirms that a bank may be undercapitalized even when it holds capital above regulatory requirements.
\end{abstract}

Keywords: capital structure, financial crisis, Portuguese banks, regulatory capital, risk

JEL Classification: G32, G38 


\section{INTRODUCTION}

The global financial crisis revealed that the existing capital regulation at the time was inadequate - in its design or implementation - to prevent a panic in the financial sector. Regardless, many of the rescued banks appeared to be in compliance with minimum capital requirements shortly before, and even during the crisis, governments around the world had to step in with emergency support to prevent a collapse. As a result, a debate ensued on how to strengthen regulation, whereas standing out that capital continues to play an important role (Khaki \& Akin, 2020; Hugonnier \& Erwanm 2017; Demirguc-Kunt et al, 2013). While many insightful discussions of liquidity and leverage requirements are available in the literature, financial theory has made little headway in developing models that can provide quantitative guidance for bank capital structure decisions and for the effects of regulatory requirements on those decisions and the resulting insolvency risk (Correia \& Martins, 2019; Grmanová \& Ivanová, 2018; Hugonnier \& Erwanm 2017; Allegret et al., 2017; Kayhan \& Titman, 2017; Van Rixtel \& Gasperini, 2013; Jucá et al., 2012; Gropp \& Heider, 2010; Frank \& Goyal, 2009).

Capital structure has been studied since 1950s by financial scholars who have proposed different theories about optimal financial structure of firms. However, financing decisions of banks remain an enigma, increasingly attracting the attention of banking regulators and corporate finance scholars alike. So far, banks have been excluded from extant studies of capital structure mainly because it was reasoned that regulation was the overriding determinant of banking capital structure. On the other hand, the cost to the economy of the global financial crisis and the scale of public support to the financial sector has been enormous. One way to reduce such costs is to have banks make greater use of equity funding Miles et al., 2012). Capital structure can be defined as the combination of debt and equity a company uses to finance its overall operations and growth, allowing analysts to identify the optimal value of the cost of capital of a company. Thus, there are three basic forms a firm can select to finance its assets: borrowing, use own profits, and issuance of shares. In other words, capital structure is a combination of debt and equity, where equity holders are the owners - having a medium to long-term commitment to the company, expecting to obtain a return on investment as payback (regular dividend or increase in stock price) - and debt holders are the creditors - having a non-long-term commitment, focusing on timely repayment of their borrowings and interests. Regarding Portugal, there are still few studies addressing to this topic, in particular with regard to the capital structure of the Portuguese banking, where a significant gap still needs to be filled. Besides, it should be noted that the Portuguese banking have suffered a tough setback in the last decade, which not only caused the collapse of some banks, but also triggered remarkable changes in the capital composition of many others, (exposed to a foreign-led concentration process in the aftermath of the eurozone crisis).

Therefore, the main objective of this research is to examine the capital structure determinants of the Portuguese banking using a sample of 18 banks for an eleven-year period (2009-2018). In addition, the study also aims to increase the knowledge about banking capital structure and to explore whether they have an aggregated or disaggregated impact on leverage. Our assumption is that the global financial crisis and the eurozone crisis have had a significant impact over the leverage ratios of the Portuguese banks, as assumed at a micro and macroeconomic levels by Correia \& Martins (2019).

\section{LITERATURE REVIEW}

The nature of banking operations plays a key role on the subject under analysis, which also implies differences in subclassification of accounts on banks' balance sheets. Thus, a major difference about Capital Structure between banks and other non-financial companies, relies on the amount of leverage effectively detained. The funding mix of non-financial corporations is rarely regulated. Companies can rely on any amount of debt funding, while striving for a balance between tax advantage of debt over equity and risk of 
leveraging. Consequently, it is rare for non-financial corporations to maintain on a regular basis less than $30 \%$ equity relative to their assets (Admati, 2016). Likewise, banks capital structure is fundamentally different from that non-financial firms because it includes deposits, a source of financing generally absent in companies (Jouida \& Hallara, 2015).

The high level of financial leverage stems from the fact the debt in banks is subsidized by deposits insurance or other implicit redeeming guarantees opposite to nonfinancial companies (Jucá et al., 2012). Because banks operate with so low equity levels and their assets are frequently opaque, banks are flimsy. Moreover, banks often choose to make pay-outs to their stockholders and continue to borrow instead of retaining their profits or sell additional shares to investors (Admati, 2016). Consequently, the profit maximization of banks` shareholders often involves hiring executives who are not risk averse, even tough their decisions could raise concerns about banks` solvency. In turn, a lack of confidence on banking and many banks become distressed all the economy is affected and impairments recognition is required (Correia \& Martins, 2019). In order to maintain confidence in banks, government regulators in many countries have introduced guaranty programs (Hull, 2015). During the financial crisis of 2007-2009, the original EU's directive of 1994 - which only required a minimum level of harmonization between domestic guarantee schemes - proved to be disruptive for financial stability and the internal market. By 2009 an amending directive required by EU countries to increase depositors' protection, firstly to a minimum of fifty thousand euros and by the end of 2010 to a level of one hundred thousand euros (European Comission, 2019).

However, the introduction of deposit insurance induces not to hold any capital given that depositors are always repaid in full up to a given amount. In any type of company on primary function of equity, is to reduce expected bankruptcy costs by lowering the payment that must be promised to creditors. Hence, banks have no incentives to hold capital in the form of deposits to the banks, and receive the same return as depositors, instead of investing on equity (Allen et al., 2015). This prompts banks to raise other forms of financing than equity, rising the need for capital regulation.

By requiring banks to hold capital, a regulator reduces bankruptcy costs that would otherwise be borne by the deposits' insurance fund (Allen et al., 2015). On the contrary, in the absence of effective regulation, deposit insurance can induce banks to take excessive risks which might conduct to banking default and failure. Due to the impact of banking failures on national economies and public finances, banking has become more and more regulated withs its capital ratios. Hence, in the aftermath of the crises occurred in 2007-2009, it was clear that banks had built up excessive leverage while apparently maintaining strong riskbased capital ratios. The underlying reason has been the proliferation of on and off-balance sheet leverage in the banking system. In response to that, the Basel Committee on Banking Supervision (BCBS) has issued the Basel III regulation. A new leverage ratio framework in order determine the minimum amount of regulatory capital banks are required to hold. However, the study let by Gropp \& Heider (2009) previously indicated that banks carry a buffer of own capital over the minimum established by the former Basel Agreements. Under Basel III regulation, this prior conclusion still needs validation.

According to DeAngelo \& Stulz (2015), regulatory limits on leverage can make sense because realworld banks do not fully internalize the costs of system -wide collapse, and so they overproduce risky liquid claims. Even tough, these authors assert that high bank leverage is not the result of moral hazard, taxes, or any other distortionary factor that could encourage banks to issue debt. The only motive for banks to issue debt comes from the value they generate by servicing the demand for socially valuable safe/liquid claims (DeAngelo \& Stulz, 2015). As an alternative to the compulsory capital requirements, Schepens (2016) proposes a more equal tax treatment of debt and equity. Based on Belgium's example of a tax shield deduction, he put into evidence that a reduction in the tax discrimination between debt and equity funding could be an important part of a regulatory incentive leading to better capitalized financial institutions. He 
demonstrated that the change in tax treatment results in an increase in bank equity but not a reduction of activities.

Even tough there is not yet an agreed optimal capital structure within banks, the very bottom line can be defined by pre-determined capital requirements established by financial regulators. However, relying on the empirical literature produced so far, we can arise some key factors that could influence banking capital structure. Thus, Berlin (2011) stated that banking literature has yet to establish convincingly whether bank capital decisions are determined by market pressures - perhaps including pressures form borrowers as well as investors - or whether they are best explained as banks meeting regulatory requirements while holding an extra equity cushion. More recently, Jouida \& Hallara (2015) and Khadi \& Akin (2020) also shared a similar perspective asserting that literature on banks has not come yet to a consensus on the determinants of capital structure. However, Khadi \& Akin (2020) found that size, tangibility, and growth opportunities have a positive impact on leverage. On the other hand, factors as profitability, age, financial constraints, liquidity, and government ownership affect leverage negatively. Frank \& Goyal (2009) corroborate those achievements by identifying six major determinants that empirically can be expected to have a significant impact on firm's capital structure: profitability, size, growth, nature of assets, industry conditions, and macroeconomic conditions. Meanwhile, Gropp \& Heider (2009) have also documented that similarities between capital structure of banks and non-financial firms could be greater than previously expected.

Relating Size, larger and more diversified firms face lower default risk (Gropp \& Heider, 2019; Sibindi \& Makina, 2018; Frank \& Goyal, 2009). However, for banks this rule has an opposite outcome. Large banks were in the epicentre of the global financial crisis (Van Rixtel \& Gasperini, 2013). Besides, systemic risk grows with bank size and is inversely related to bank capital. Nevertheless, size of large banks has increased substantially over the last two decades (Laeven et al., 2016). This research has evidenced that systemic risk increases with bank size. Complimentarily, that systemic risk is lower in more-capitalized banks, with the effects particularly more pronounced for large banks. Tin \& Diaz (2017) have found that bank size is the most consistent variable affecting leverage in the three groups of banks (Vietnamese large, medium, and small banks).

Growth and leverage have been considered positively correlated by several authors indistinctly for nonfinancial and financial firms (Khaki \& Akin, 2020; Sibindi \& Makina, 2018; Sorokina et al., 2017; Jouida \& Hallara, 2015; Gropp \& Heider, 2010; Frank \& Goyal, 2009). Thus, leverage often rises as natural enabler in the absence of enough owned resources, or when tax shields are rewarding in terms of financial decisions.

Another determinant under analysis is Collateral, assessed as a given security for loans. According to Jouida \& Hallara (2015) it is positively related to debt. Holding a high portion of tangible assets, this may serve as collateral in the insurance debt. Using collateral, the moral hazard concerning debt can be reduced which lowers the costs of debt enabling firms to be more levered. In fact, this assumption is aligned with the evidences provided by Khaki \& Akin (2020) relating the positive correlation between tangibility and leverage.

Frank \& Goyal (2009) and Gropp \& Heider (2010) conclude that companies and banks which pay dividends are more profitable and, therefore, less leveraged. However, during periods of financial hardship, paying dividends is not recommendable for firms with high leverage and/or low profitability. -dividends were also considered as a factor of main importance for banks' capital structure (Sorokina et al., 2017; Jouida \& Hallara, 2015). In terms of the factor Risk, DeAngelo \& Stulz (2015) declared that risk management provides the critical asset-side foundation that enables banks to produce large amounts of safe/liquid claims. The concern arises when riskier banks, close to the minimum regulatory capital do not adjust to their capital structure towards more equity, potentially endangering all banking system. Thus, banking sector greatly depends on the adequacy of liquidity flows and a solid risk assessment on the asset-side, making risk as well a first-order importance factor explaining banks' capital structure. 
Most of the literature on finance do not consider Capital Requirements as a main factor influencing the choice of capital structure by banks. However, most of the researches were undertaken before or during a transition period when Basel III was being implemented. As suggested by Sibindi \& Makina (2018), our intention by adding a supplementary variable, is to examine the impact of the implementation of these new capital standards on the financing patterns of banks and assess how these new binding rules have impacted on capital structure decisions of the Portuguese banking, as a country that requested financial assistance over the last European crisis (Correia \& Martins, 2019).

\section{METHODOLOGY}

The study aims to examine whether the standard determinants of corporate capital structure defined by the empirical literature also apply to Portuguese banks in the last eleven years' period (2008-2018). In this scope, were defined the following specific objectives: (i) analyze to what extent the financial leverage of the Portuguese banks is correlated with firm-level capital determinants; (ii) assess whether regulatory capital exerts influence over the capital structure of Portuguese banks; (iii) evaluate whether capital structure of the Portuguese banking, in the period from 2008 to 2012 (global financial crisis and eurozone crisis), shows significant differences compared to the subsequent period 2013-2018. Therefore, it will be possible to validate whether the capital determinants drivers, raised by empirical literature, have the same correlation within Portuguese banking.

The research has followed a positivist research approach (Lopes, 2015), which assumes the existence of an independent and autonomous reality, either independent from the searcher perspective and its personal beliefs. Positivism is commonly described as an epistemology that seeks explanations of events in order to disclose their underlying laws. Therefore, is frequently associated to exact sciences, whereas relies on mathematical and statistical methods to find unbiased results. In this sense, this approach enables the author to validate the investigation hypotheses and the empirical knowledge regarding the investigation problem through statistical and mathematical methods. In this sense the research is empirically observable inducting reasonings used to raise hypotheses which are tested within the study confirming or denying the theory.

The population for this study was selected based on the banks indicated in the 2018 Statistical Bulletin of the Portuguese Bank Association, considering as main premise: institutions that have been functioning continually in Portugal over the last eleven years (2008-2018). Besides, for the above mentioned sampling frame, banks fitting in one of the following categories have also been exempted: (1) banks with a blended composition (such as the group of Caixas de Crédito Agricola); and, (2) banks that have been shut down due to bankruptcy or assimilated by other financial institutions. The required financial information concerning the banks was obtained from the corporate governance and annual financial reports, publicly available on the website of the "Banco de Portugal" (Central Bank of Portugal) as well as at the official websites of each bank for the fiscal years comprehending the period from 2008 to 2018. Accordingly, it was expected 198 observations, although only 184 observations were confirmed to all variables due to lack of data on some banks. The analysis was conducted using STATA version 16, through a panel data analysis.

\section{Variables}

In our research, we use underlying factors that were found significant in several researches (Kahi \& Akin, 2020; Sibindi \& Makina, 2018; Sokorina et al., 2017; Tin \& Diaz, 2017; Gibson et al., 2016; Sibindi \& Makina, 2018; Laeven et al., 2016; Sha `ban et al., 2016; Jouida \& Hallara, 2015; Gropp \& Heider, 2010; Frank \& Goyal, 2009). Data concerning the analyzed banks was directly obtained from disclosed annual statements 
or calculated on its basis. Therefore, the following table presents both dependent and independent variables utilized in this study.

Regarding both dependent and independent variables, we took into consideration metrics previously used in the reference literature, trying to adapt them to our study as much as possible. To measure Banks' capital structure, the dependent variable selected was book leverage, in harmony with the leverage definition (Sibindi \& Makina, 2018). In this scope, the main goal is to measure how much capital comes in the form of debt, and by that, perceive how the bulk of assets is being funded. In relation to independent variables, the regressors selected mainly correspond to bank-level determinants of capital structure found in the empirical literature, including two dummy variables, DIV and CRIS. However, the last one, jointly with RCAP, have been an innovation of our research, aiming to capture the economic cycle effects of the crises (Global financial crisis and eurozone crisis), as well as to assess the effects of the mandatory capitalization of the Portuguese banks determined by the regulators. A natural logarithm was used for the variable Size. Taking the value of total assets for each bank, this method enables the adjustment of the values into a comparable size scale, making banks comparable in terms of dimension. In relation to the variable growth, the selected proxy has been annual variance of total assets, considering that a change on assets total value presents inflows or outflows of capital, and thus, impacting on capital structure. This metric was also utilized in order to measure the dependent variable growth, according to Sibindi \& Makina (2018). Concerning risk, our initial intention was to use the Non-Performing Loans (NPL) ratio as a proxy. However, due to the lack of disclosed information for every bank, our option was an alternative indicator based on impairment of loans to gross loans. The dependent variable collateral was obtained by summing up several balance sheet items then divided those items by the book value of total assets. This metric is consistent with the equivalent collateral variable found on former studies carried out by DeAngelo \& Stulz (2015) and Gropp \& Heider (2010). The dummy variables employed in this study intended to detect the effects of the global financial crisis and the eurozone crisis (2008-2012), as well as a dummy variable to capture one of the remaining firm-level determinants of capital structure: payment of dividends.

Table 1

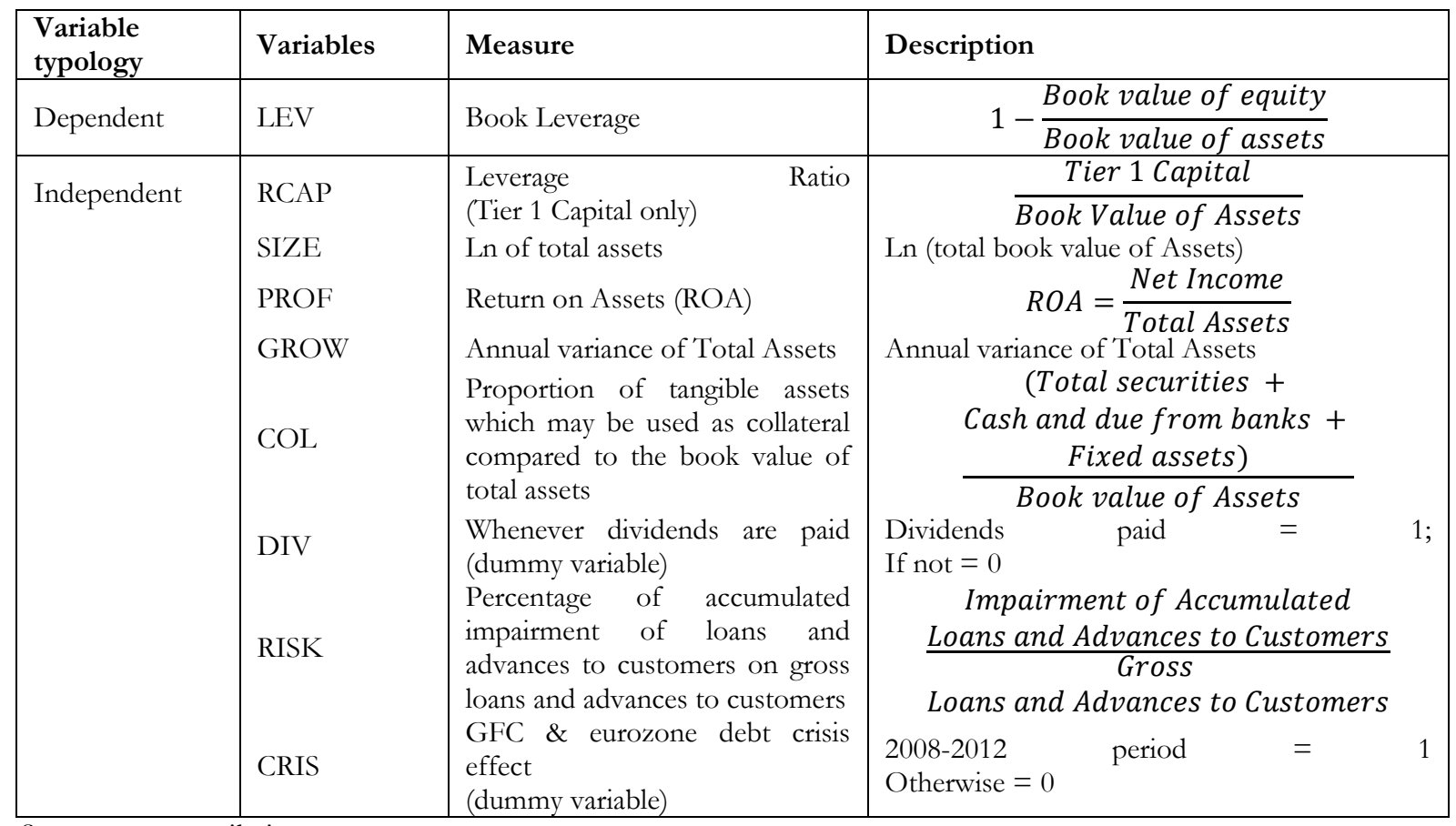

Source: own compilation 


\section{Regression model and hypotheses}

In order to identify which capital determinants, contribute the most to explain the capital structure of Portuguese banks, a multiple linear regression model was put in place. When applying multiple regression, we construct a model to explain variability in the dependent variable, which concomitantly enables to determine the simultaneous effect of several independent variables on the dependent variable. Thus, the data is analyzed by conducting a regression analysis for panel data, in order to determine to what extent standard firm-level determinants of capital structure apply to the Portuguese banking.

The simplest model to analyze our data set, was the pooled ordinary least squares (OLS) model. However, OLS can only be utilized when some required conditions are previously ensured - for instance: the error terms have the same variance (which is referred to homoscedasticity); there is no correlation between the errors; and there is no correlation between errors terms and explanatory variables. As the banks are repeatedly observed, it can be predicted that the error terms from different time periods might be correlated. Because of these limitations, more developed models have been employed in this research. Other than the pooled OLS, there are two alternative techniques used to analyze panel data: Fixed Effects (FE) and Random Effects (RE). To decide which model (OLS, fixed or random effects) adjusts better, several tests can be conducted. In this scope, we have applied in two stages Breusch-Pagan and Hausman tests, in order to decide which model could better adjust to our study. Therefore, this model aims to explain to what extent standard firm-level determinants of capital structure apply to the Portuguese banking:

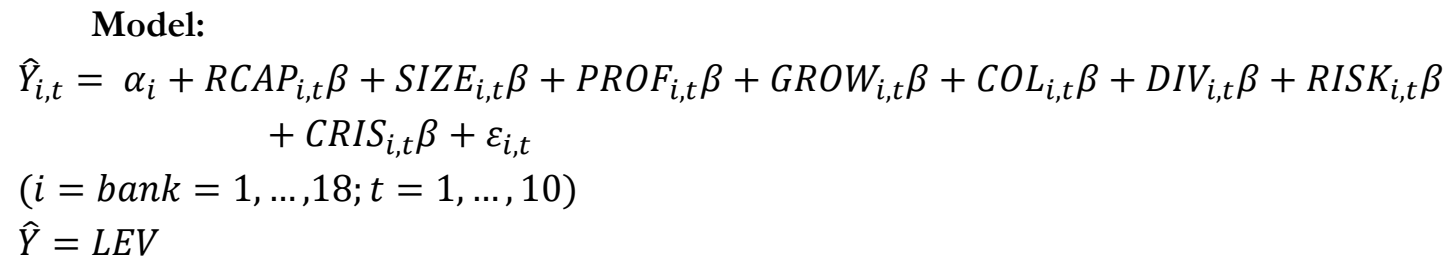

The variables were all introduced simultaneously through stepwise method in order to determine which are statistically significant to predict banking leverage. In line with the raised regression model, the following hypothesis and sub-hypothesis were tested through econometric analysis: $\mathrm{H}_{0}$ states that independent variables have no explanatory power on Portuguese banks' book leverage; and $\mathrm{H}_{1}$ otherwise.

\section{Efficiency analysis}

Using Stata software, the reliability of the regression was ensured by analyzing which model would best adapt to the panel data found for the study. Breusch-Pagan and Hausman tests were also conducted, concluding that the appropriate model for our regression was the FE model. In this context, heteroscedasticity and endogeneity presence in the model has been controlled, ensuring the robustness and reliability of results obtained. Besides, the Variance Inflation Factor (VIF) detects multicollinearity in regression analysis. Multicollinearity occurs when there is a high correlation between regressors (independent variables) and its presence can adversely affect regression model results. The VIF estimates how much the variance of a regression coefficient is inflated due to multicollinearity, ranging from one upwards (a VIF value above 10 indicates high correlation and is cause for concern). Regarding our model, we find that none of the independent variables has a VIF value greater than 1,7 allowing to conclude that the analysis does not observe a severe problem of multicollinearity.

Descriptive Statistics are displayed below. As already mentioned, our sample consists of 18 banks for a eleven-years period analysis (2008-2018). Thus, 198 observations were expected. However, only 184 have 
been effectively verified for every indicator, due to the lack of certain financial data disclosed by the banks in their financial statements.

Table 2

Descriptive measures

\begin{tabular}{|l|c|c|c|c|c|c|}
\hline Variable typology & Variable & $\mathbf{N}$ & Minimum & Maximum & Mean & $\begin{array}{c}\text { Standard } \\
\text { Deviation }\end{array}$ \\
\hline Dependent & LEV & 184 & 0.5730 & 0.9990 & 0.913291 & 0.0558760 \\
\hline \multirow{4}{*}{ Independent } & RCAP & 184 & 0.0184 & 0.3284 & 0.088862 & 0.0735858 \\
\cline { 2 - 7 } & SIZE & 184 & 10.5389 & 19.5314 & 16.02456 & 1.9554764 \\
\cline { 2 - 7 } & PROF & 184 & -0.0570 & 0.2791 & 0.087674 & 0.0453859 \\
\cline { 2 - 7 } & GROW & 184 & -0.6751 & 2.9879 & 0.079344 & 0.3837639 \\
\cline { 2 - 7 } & COL & 184 & 0.0089 & 0.9927 & 0.479741 & 0.2985930 \\
\cline { 2 - 7 } & RISK & 184 & 0.0000 & 0.4315 & 0.074765 & 0.0631767 \\
\hline
\end{tabular}

Source: own compilation

Analyzing the obtained results, some considerations can be drawn. On the dependent variable (Book Leverage) the mean registered a percentage of $91.3 \%$ and a standard deviation of $5.6 \%$ evidencing in most Portuguese banks a low degree of financial autonomy, although in line with previous findings by related empirical literature.

Regarding the independent variables, it should be highlighted the following aspects: (1) $41 \%$ of the banks have paid dividends during the years considered; (2) Profitability (whose selected proxy has been ROA), reveals a mean of 0.078 , lower when compared to the similar empirical studies regarding European banks (Gibson et al., 2016; Miles et al., 2012). In relation to the dividends policy followed by the banks, we found no differences between the crisis period (2008-2012) and the post-crisis phase (2013-2018). Conversely to the expectations, the observations evidence a similar conduct in what refers to dividends' payment: 54 banks have not paid dividends during 2008-2012, which do not differ much from the 53 banks who have not also paid dividends in the subsequent period. We understand this outcome as a probable consequence of the polices taken by the regulator after the crisis (2008-2012) - in order to increase capital ratios in accordance to the new Basel III capital requirements - which forced banks to strengthen their capital ratios rather than paying dividends to their shareholders.

Bivariate correlation analysis was steered through Pearson correlation coefficients in order to evaluate whether there is any relationship between the variables and its respective strength. Correlation analysis expresses the linkage between two variables and values will always be between +1 and -1 . The sign indicates the direction, whether the correlation is positive or negative, and the value, called correlation coefficient, measures the strength of the correlation. A correlation coefficient of zero indicates no relationship between the variables at all. Additionally, the significance level is the probability of rejecting the null hypothesis when it is true. In general, results with a significance level of 0.05 (5\% error probability) are considered statistically relevant. In this way, it is said that the result is statistically significant when the observed p-value is less than the parameter defined for the study. The following matrix evinces the relationship between the variables presented in this study when combined two by two. 
Pearson correlation coefficients

\begin{tabular}{|c|c|c|c|c|c|c|c|c|c|}
\hline VAR. & $\mathrm{LEV}$ & RCAP & SIZE & PROF & GROW & COL & DIV & RISK & CRIS \\
\hline LEV & 1 & & & & & & & & \\
\hline RCAP & $\begin{array}{l}-0.971^{\text {** }} \\
0.000\end{array}$ & 1 & & & & & & & \\
\hline SIZE & $\begin{array}{l}0.631^{* *} \\
0.000\end{array}$ & $\begin{array}{l}-0.517^{* *} \\
0.000\end{array}$ & 1 & & & & & & \\
\hline PROF & $\begin{array}{l}-0.316^{* *} \\
0.000\end{array}$ & $\begin{array}{l}0.613^{* *} \\
0.000\end{array}$ & $\begin{array}{l}-0.272^{* *} \\
0.001\end{array}$ & 1 & & & & & \\
\hline GROW & $\begin{array}{l}0.047 \\
0.633\end{array}$ & $\begin{array}{l}0.007 \\
0.818\end{array}$ & $\begin{array}{l}0.096 \\
0.318\end{array}$ & $\begin{array}{l}0.026 \\
0.918\end{array}$ & 1 & & & & \\
\hline $\mathrm{COL}$ & $\begin{array}{l}-0.419^{* *} \\
0.000\end{array}$ & $\begin{array}{l}0.485^{* *} \\
0.000\end{array}$ & $\begin{array}{l}-0.594^{* *} \\
0.000\end{array}$ & $\begin{array}{l}0.217 \\
0.071\end{array}$ & $\begin{array}{l}-0.119 \\
0.711\end{array}$ & 1 & & & \\
\hline DIV & $\begin{array}{l}-0.283^{* *} \\
0.007\end{array}$ & $\begin{array}{l}0.174^{* *} \\
0.006\end{array}$ & $\begin{array}{l}0.032 \\
0.867\end{array}$ & $\begin{array}{l}-0.192^{*} \\
0.024\end{array}$ & $\begin{array}{l}-0.096 \\
0.357\end{array}$ & $\begin{array}{l}-0.119 \\
0.153\end{array}$ & 1 & & \\
\hline RISK & $\begin{array}{l}-0.106 \\
0.201\end{array}$ & $\begin{array}{l}0.061 \\
0.433\end{array}$ & $\begin{array}{l}0.031 \\
0.814\end{array}$ & $\begin{array}{l}0.188 \\
0.143\end{array}$ & $\begin{array}{l}-0.024 \\
0.731\end{array}$ & $\begin{array}{l}-0.187 \\
0.098\end{array}$ & $\begin{array}{l}-0.118 \\
0.172\end{array}$ & 1 & \\
\hline CRIS & $\begin{array}{l}0.189^{*} \\
0.043\end{array}$ & $\begin{array}{l}-0.176^{*} \\
0.033\end{array}$ & $\begin{array}{l}-0.027 \\
0.719\end{array}$ & $\begin{array}{l}-0.275^{*} \\
0.041 \\
\end{array}$ & $\begin{array}{l}0.121 \\
0.327\end{array}$ & $\begin{array}{l}0.029 \\
0.832\end{array}$ & $\begin{array}{l}0.019 \\
0.851 \\
\end{array}$ & $\begin{array}{l}-0.238^{* *} \\
0.003\end{array}$ & 1 \\
\hline
\end{tabular}

Notes: $* * \mathrm{p}<0.01 ;{ }^{*} \mathrm{p}<0.05$

Source: own compilation

In relation to the influence of capital structure determinants, the null hypothesis can be rejected at a $1 \%$ level of significance for the variables RCAP, SIZE, PROF, COL and DIV. Beyond that the null hypothesis can also be rejected at a 5\% level of significance for the variable CRIS. Relatively to the variable size, results corroborate the findings achieved by several researchers (Khadi \& Akin, 2020; Gropp \& Heider, 2019; Sibindi \& Makina, 2018; Sha 'ban et al., 2016), which also stated that leverage is positively correlated with size. This evidence also aligns with the trade-off theory of capital structure, since larger banks tend to be highly levered compared to small banks, (inasmuch as the last ones face higher debt interest rates). Thus, they found that size is negatively correlated with leverage. Leverage is inversely correlated with profitability, and the correlation is highly significant, corroborating the evidences provided by Khadi \& Akin (2020). This can be explained premised on the predictions of the pecking order theory (Shyam-Sunder \& Myers, 1999). The more profitable a bank is, the more likely that will generate reserves than rely on debt to fund its assets (Gropp \& Heider, 2019). Concerning collateral, our result (collateral is negatively correlated with leverage) also aligns with the evidence found, which states that leverage is negatively correlated with collateral (khaki \& Akin, 2020; Jouida \& Hallara, 2015). Thus, the correlation coefficient for the variable dividends, consolidates the literature confirming that leverage is significantly correlated with dividends (Gropp \& Heider, 2019; Sha 'ban et al., 2016; DeAngelo \& Stulz, 2015; Grop \& Heider, 2010; Frank \& Goyal, 2009).

\section{EMPIRICAL RESULTS AND DISCUSSION}

A Multiple Linear Regression (MLR) examines how several explanatory (independent) variables are related to one dependent variable. Thereby, a MLR was employed in order to realize if there is a statistically significant relationship between the independent variables and the dependent variable, allowing to gauge about the effects of the capital structure determinants on Portuguese banks' leverage over the period 20082018. The regression equation for Model results are evidenced in the table below. 
Regression model equation

\begin{tabular}{|c|c|c|c|c|}
\hline & $\beta(\mathrm{Std})$ & $\mathrm{t}$ & $\mathrm{P}>|\mathrm{t}|$ & VIF \\
\hline RCAP & -0.6842913 & -2.41 & $0.019^{*}$ & 1.710 \\
\hline SIZE & 0.01984273 & 0.13 & 0.331 & 1.640 \\
\hline PROF & -0.0621339 & -0.97 & 0.379 & 1.645 \\
\hline GROW & -0.0006385 & -0.34 & 0.814 & 1.208 \\
\hline $\mathrm{COL}$ & 0.0184123 & 0.57 & 0.644 & 1.619 \\
\hline DIV & 0.0017443 & 0.22 & 0.873 & 1.415 \\
\hline RISK & 0.0227719 & 0.09 & 0,934 & 1.132 \\
\hline CRIS & 0.0315874 & 2.99 & $0.000^{* *}$ & 1.187 \\
\hline CONSTANT & 0.6632467 & 2.47 & $0.030^{*}$ & \\
\hline \multicolumn{5}{|c|}{$\begin{array}{c}\text { Adjusted R-sq }=0.4187 \\
\text { Prob }>\mathrm{F}=0.0001\end{array}$} \\
\hline
\end{tabular}

Notes: ${ }^{* *} \mathrm{p}<0.01 ;{ }^{*} \mathrm{p}<0.05$.

Source: own compilation

As stated in the table above, the coefficient of determination is 0.4187 in the model, which express the variation of LEV by independent variables. It is a widely used indicator since it expresses the explanatory power of a regression model. Based on this integrated model, this means that our model explains in aprox. $41.9 \%$ of the variance of Portuguese banks' leverage over the period 2008-2018. However, as initially expected, the results obtained allow to conclude that two of the explanatory variables are statistically significant, whereas: RCAP (standardized $\beta=-0.6843 ; \mathrm{p}=0.019$ ), present a negative impact on dependent variable LEV; while predictor CRIS (standardized $\beta=0.0315 ; \mathrm{p}<0.001$ ) offer a positive effect over LEV. Thus, we present in the next table the final model, which integrates the two variables statistically significant.

Table 5

Regression model equation (RCAP and CRIS variables)

\begin{tabular}{|l|c|c|c|c|}
\hline & $\beta(\mathrm{Std})$ & $\mathrm{t}$ & $\mathrm{P}>|\mathrm{t}|$ & VIF \\
\hline RCAP & -0.3342408 & -1.98 & $0.000^{*}$ & 1.112 \\
\hline CRIS & 0.0275389 & 1.19 & $0.000^{* *}$ & 1.251 \\
\hline CONSTANT & 0.4233769 & 1.53 & $0.012^{*}$ & \\
\hline $\begin{array}{l}\text { Adjusted R-sq }=0.3412 \\
\text { Prob }>\mathrm{F}=0.0001\end{array}$
\end{tabular}

Source: own compilation

Final Model:

$\widehat{L E V}_{i, t}=0,423-0.334_{i, t} \beta+0,028_{i, t} \beta+\varepsilon_{i, t} \quad(i=\operatorname{bank}=1, \ldots, 18 ; t=2008, \ldots, 2018)$

Relatively to RCAP, the finding is in line with the evidence found (Allegret et al., 2017), that capital requirements do introduce a non-linearity in the behaviour of banks when capital falls to levels very close to the regulatory minimum. Besides, in regard to the second regressor (CRIS), a strong connection between bank funding and financial crises (global financial crisis and eurozone crisis) can also be found in literature. Van Rixtel \& Gasperini (2013) have clearly exposed that ultimately, these strains (on the asset side of banks' balance sheets) expose growing problems in the quality of the underlying assets, leading to fire sales of assets which accelerate declines in asset prices, resulting in further balance sheet pressures. Throughout this process, funding liquidity crises can exacerbate solvency concerns. These tensions feed on imbalances in bank funding structures, such as excessive recourse to debt financing that is reflected in historically high degrees of leverage. Thus, global financial crisis and euro sovereign debt crisis had a significant negative 
effect on equity capital held by European banks (Sha 'ban et al., 2016; Jouida \& Hallara, 2015). All the other independent variables are not statistically significant to explain the model, which only leads to the rejection of some sub-hypothesis (except those associated with RCAP and CRIS variables).

The reliability of the model was assessed through statistical inference. Primarily, it is important to verify the normal distribution of the sample and residuals. According to the Central Limit Theorem, as the sample size gets larger, its means tend to a normal distribution. This is especially true in samples whose size is bigger than 30. Considering that the sample in this study consists of 184 observations, it is assumed that it has a normal distribution. Nevertheless, this assumption was verified in each model's histogram and normal P-P plot of regression standardized residual. Regarding the independence of residuals, the Durbin-Watson test was executed, estimating values approximated to 2 , proving there is no autocorrelation between the errors. The homoscedasticity of the residuals was assumed due to the fact that they present a normal distribution and the mean of the residuals is zero. From each model's scatterplot is possible to undertake that the residuals' variance is homogeneous. The assumption of the linear relation between the dependent and independent variables on $\beta$ coefficients was also assessed for the models through the random distribution of the residuals. Furthermore, the models presented absence of multicollinearity, with Variance Inflation Factor (VIF) assuming values significantly inferior to 10 and tolerance inferior to 1 for each independent variable. This allows concluding that the explanatory variables are not correlated.

Table 6

Variables comparison between periods (2008-2012 Vs. 2013-2018)

\begin{tabular}{|c|c|c|c|c|c|c|}
\hline Variable & $\begin{array}{c}\text { Equality of } \\
\text { Variances } \\
\text { (F) }\end{array}$ & Sig. & $\begin{array}{c}\text { Equality of } \\
\text { Means } \\
(t)\end{array}$ & $d f$ & Sig. & Hypothesis Test (U) \\
\hline LEV & 1.886 & 0.121 & -2.119 & 182 & $0.041^{*}$ & Rejected \\
\hline RCAP & 9.810 & $0.001^{* *}$ & 2.397 & 182 & $0.023^{*}$ & Rejected \\
\hline SIZE & 2.374 & 0.183 & 0.515 & 182 & 0.536 & Not Rejected \\
\hline PROF & 6.912 & $0.011^{*}$ & 2.191 & 182 & $0.026^{*}$ & Rejected \\
\hline GROW & 2.642 & $0.046^{*}$ & -2.318 & 182 & $0.018^{*}$ & Rejected \\
\hline $\mathrm{COL}$ & 5.057 & $0.026^{*}$ & -2.337 & 182 & 0.713 & Not Rejected \\
\hline DIV & 0.191 & 0.619 & -0.163 & 182 & 0.770 & Not Rejected \\
\hline RISK & 0.627 & 0.617 & 3.118 & 182 & $0.002^{* *}$ & Rejected \\
\hline
\end{tabular}

Source: own compilation

The results suggest that there are statistically significant differences between the two periods, whereby the null hypothesis (no difference between the two periods) can be rejected for the variables LEV, RCAP, PROF, GROW and RISK. Therefore, as expected, the bottom line that can be taken, is that GFC and eurozone crisis have had a significant impact over Portuguese banking affecting not only its solvability, but also their profitability, growth and risk.

From an economic point of view this stance is also corroborated. Since 2007, and more clearly since 2010, Portuguese banks have experienced a sharp decline on profitability in result of a significant increase on impairments value (a condition which have just reversed in recent years), which has combined with a deterioration on the net interest income of the Portuguese banks. Simultaneously, the decline in asset prices (in part due to the increase of impairments as well), along with the escalation of non-performing loans ratio, have conducted to a rise on risk indicators during the peak of the eurozone crisis (2010-2012) - which still poses some persistence across certain institutions of the banking system. Nevertheless, concerning leverage, a significant increase in solvency levels has been noticed after the crisis period (2008-2012). Presumably as consequence of the higher regulatory requirements. 


\section{FINAL REMARKS}

\section{Conclusions}

This paper examines the Capital Structure of the Portuguese banks building on empirical capital structure literature for banking industry. Our research contributes to the literature by extending the study on main capital structure determinants to the Portuguese banking, deepening the knowledge about the funding of the Portuguese banks in the last years. We use a sample of 18 Portuguese banks covering the period of global financial crisis and eurozone crisis (2008-2018). The gathered sample includes commercial banks, investment banking and consumer credit banking. The specific objectives consist on: (i) analyze to what extent the financial leverage of the Portuguese banks is correlated with firm-level capital determinants; (ii) assess whether regulatory capital exerts influence over the capital structure of Portuguese banks; (iii) evaluate whether capital structure of the Portuguese banking, in the period from 2008 to 2012 (global financial crisis and eurozone crisis), shows significant differences compared to the subsequent period 20132018.

The analysis conducted employs descriptive and association measures, a multiple linear regression model and an independent sample t-test. The study examines seven bank-specific factors (i.e.: regulatory capital, size, profitability, collateral, growth, dividends payment) and one economic variable (crisis prevalence) influencing capita structure with book leverage as the dependent variable. Regressing the panel data through the Fixed Effects model, we found some factors that significantly impact on Portuguese banking capital structure, namely regulatory capital and crisis.

With regard to correlation analysis, our findings are in line with the predictions of the major theories. Relatively to the variable size, results corroborate the findings achieved by other researchers (Khaki \& Akin, 2020; Allegret et al., 2017; Miles et al., 2015), which also stated that leverage is positively correlated with size. Besides, leverage is inversely correlated with profitability, which can be explained premised on the predictions of the pecking order theory. The more profitable a bank is, the more likely that will generate reserves than rely on debt to fund its assets. Concerning the variable collateral, our result aligns with the evidence found in similar approaches (Sha'ban et al., 2016; Gropp \& Heider, 2010), which states that leverage is negatively correlated with collateral. For the variable dividends, the correlation coefficient, consolidates the literature confirming that leverage is significantly correlated with dividends (Allegret et al., 2017). This research also assesses on the impact of the crisis over the variables by splitting the period in two stages (2008-2012: crisis period vs. 2013-2018: post-crisis period). Results suggest that the distribution of leverage is different among periods for the predictors RCAP, PROF, GROW and RISK.

Broadly, the outcomes of this research confirm that Portuguese banks' capital structure is not exclusively, neither merely, determined by capital regulations, giving support to the view which extends conventional determinants of capital structure for non-financial firms to banks (Tin \& Diaz, 2017; DeAngello \& Stulz, 2015; Gropp \& Heider, 2010). However, it was quite clear that during the period under review, regulatory capital as well as the economic effects of the financial crisis strongly impacted on the leverage ratios of Portuguese banks. In a first phase by reducing the proportion of capital, followed by a second phase of strengthening the capital adequacy ratios.

In spite of limitations, due to unrevealed data by some banks, the independent variable regulatory capital shows few missing values. Nevertheless, we were able to partially demonstrate that Portuguese banking corroborates the empirical principle that regulatory requirements eventually influence banks' capital structure, whenever it approaches the required minimum forcing regulators to intervene. The past events since 2008, which led regulators to impose capital reinforcements on Portuguese banks, take us to believe that this observation has also a significant statistical translation. On the other hand, the difficulties selecting 
the metrics' as proxies for the study's predictors, might implies some bias of a better match with the previous empirical results about this subject.

Finally, our study opens additional paths for future research. Thereby, there are still different approaches to be explored within Portuguese banking capital structure. Therefore, it would be interesting to investigate what is the relationship between size and bank leverage or investigate how equity held by banks can be influenced by performance or risk taking. Moreover, it would be also interesting to study how sovereign debt ratings had specifically affected bank solvency. Additionally, new proxies for capital structure determinants and an analysis extended over a longer period would also contribute to enrich the knowledge about Portuguese banking capital structure. Hence, and given the economic risks looming over the horizon, it is essential that Portuguese banking stakeholders in their assessment of bank security and soundness, take in consideration that a bank may be undercapitalized even when it holds capital above regulatory requirements (Sorokina et al., 2017).

\section{Further directions and recommendations}

This research opens additional paths for future research. Thereby, there are still different approaches to be explored within European banking capital structure, and, relating Portuguese banking capital structure. We strongly recommend that researchers could corroborate outcomes and/or follow other directions such as: (a) investigate what is the relationship between size and bank leverage; (b) investigate how equity held by banks can be influenced by performance or risk taking; (c) investigate how sovereign debt ratings had specifically affected bank solvency. Additionally, new proxies for capital structure determinants could be explored and/or extend the current analysis over a long period.

\section{REFERENCES}

Admati, A. (2016). The missed opportunity and challenge of capital regulation. National Institute Economic Review, 235(1), 4-14.

Allen, F., Carletti, E., Marquez, R. (2015). Deposits and bank capital structure. Journal of Finance and Economics. 118(3), 601-619. doi: https//dx.doi.org/10.1016/j.jfineco.2014.11.003

Allegret, J. P., Raymond, H., \& Rharrati, H. (2017), The impact of the European sovereign debt crisis on bank stocks. Some evidence of shit contagion in Europe. Journal of Banking and Finance, 74(1), 24-37. https://doi.org/10.1016/j.jbankfin.2016.10.004

Berlin, M. (2011). Can we explain banks' capital structures?. Business Review. Federal Reserve Bank of Philadelphia, issue Q2, $\quad$ Retrieved $\quad$ August $\quad 20, \quad 2020$ from https://citeseerx.ist.psu.edu/viewdoc/download?doi=10.1.1.417.1408\&rep=rep1\&type=pdf

Correia, L., Martins, P. (2019). The European crisis: analysis of the macroeconomic imbalances in the rescued euro area countries. Journal of International Studies, 12(2), 22-45. doi: https// dx.doi.org/10.14254/2071-8330.2019/12$2 / 2$

DeAngelo, H., \& Stulz, R. (2015). Liquid-claim production, risk management, and bank capital structure: Why high leverage is optimal for banks, Journal of Financial Economics, 112(2), 219-236. doi: https://dx.doi.org/10.1016/j.jfineco.2014.11.011

Demirguc-Kunt, A., Detragiache, E., \& Merrouche, O. (2013). Bank Capital: Lessons from the Financial Crisis, Journal of Money, Credit and Banking, 45(6), 1147-1164. doi: https://dx.doi.org/10.1111/jmcb.12047

European Commission (2019). European Commission - Deposit guarantee schemes. Retrieved October 25, 2020 from https://ec.europa.eu/info/business-economy-euro/banking-and-finance/financial-supervision-and-riskmanagement/managing-risks-banks-and-financial-institutions/deposit-guarantee-schemes en

Frank, M., \& Goyal, V. (2009). Capital structures decisions: which factors are reliably important, Financial Management, 38(1), 1-37. doi: https://dx.doi.org/10.1111/j.1755-053X.2009.01026.x 
Gibson, H., Hall, S., \& Tavlas, G. (2016). How the Euro-Area Sovereign-Debt Crisis led to a Collapse in Bank Equity Prices, Journal of Financial Stability, 26(C), 266-275. doi: https//dx.doi.org/10.1016/j.jfs.2016.07.010

Gramanová, E., \& Ivanová, E. (2018). Efficiency of banks in Slovakia: Measuring by DEA models. Journal of International Studies, 11(1), 257-272. doi: https//dx.doi.org/10.14254/2071-8330.2018/11-1/20

Gropp, R., \& Heider, F. (2010), The Determinants of Bank Capital Structure, Review of Finance, 14(4), 587-622. doi: https://dx.doi.org/10.1093/rof/rfp030

Hugonnier, J. \& Erwan, M. (2017). Bank capital, liquid reserves, and insolvency risk, Journal of Financial Economics, 125(2), 266-285. doi: https//dx.doi.org/10.1016/j.jfineco.2017.05.006

Hull, J. C. (2015). Risk Management and Financial Institutions, Fourth Edition, New Jersey: John Wiley \& Sons.

Laeven, L., Ratnovski, L., \& Tong, H. (2016). Bank size, capital, and systemic risk: some international evidence. Journal of Banking and Finance, 69(1), 25-34. doi: https://dx.doi.org/10.1016/j.jbankfin.2015.06.022

Jouida, S., \& Hallara, S. (2015). Capital structure and regulatory capital of French banks. Procedia Economics and Finance, 26(1), 892.902. https://doi.org/10.1016/S2212-5671(15)00901-6

Jucá, M. N., Sousa, A. F., \& Fishlow, A. (2012). Capital structure determinants of Brazilian and North American Banks, International Journal of Business and Commerce, 1(5), 44-63.

Lopes, I. (2015). Research methods and methodology towards knowledge creation in accounting, Contaduria $y$ Administración, 60 S1, 9-30. https//doi.org/10.1016/j.cya.2015.08.006

Kayhan, A., \& Titman, S. (2007). Firms' history and their capital structures, Journal of Financial Economics, 83(1), 1-32. https://doi.org/10.1016/j.jfineco.2005.10.007

Khaki, A. R., \& Akin, A. (2020). Factors affecting the capital structure: New evidence from GCC countries. Journal of International Studies, 13(1), 9-29. https// doi.org/10.14254/2071-8330.2020/13-1/1

Miles, D., Yang, J., \& Marcheggiano, G. (2012). Optimal bank capital, The Economic Journal, 123(567), 1-37. https://doi.org/10.1111/j.1468-0297.2012.02521.x

Schepens, G. (2016). Taxes and bank capital structure. Journal of Financial Economics, 120(3), 585-600. https://doi.org/10.1016/j.jfineco.2016.01.015

Sha'ban, M., Girardone, C., \& Sarkisyan, A. (2016). The determinants of Bank Capital structure: A European Study, Colchester: Essex Business School.

Shyam-Sunder, L., \& Myers, S. (1999). Testing static trade off against pecking order models of capital structure. Journal of Financial Economics, 51(1), 219-244.

Sibindi, A. B., \& Makina, D. (2018). Are de determinants of banks' and insurers' capital structures homogenous? Evidence using South African data, Cogent Economics and Finance, 6, 1-21. https://doi.org/10.1080/23322039.2018.1519899

Sorokina, N. Y., Thornton, J. H., \& Patel, A. (2017). Why do banks choose to finance with equity? Journal of Financial Stability, 3(C), 36-52. https://doi.org/10.1016/j.jfs.2017.04.002

Tin, T., \& Diaz, J. (2017). Determinants of banks' capital structure: evidence from Vietnamese commercial banks. Asian Journal of Finance and Accounting, 9(1), 261-284. https://doi.org/10.5296/ajfa.v9i1.11150

Van Rixtel, A., \& Gasperini, G. (2013). Financial crises and bank funding: recent experience in the euro area, BIS Working paper $n^{\circ} 406$, Bank for International Settlements. 